\title{
Social Status of Nepalese Single Women and Perception on Remarriage: A Case Study of Pokhara Lekhnath Metropolitan City
}

\author{
Surendra Tiwari \\ School of Development and Social Engineering \\ Email: rsuren77@gmail.com \\ Sabitri Bhattarai (Kaphle) \\ School of Development and Social Engineering \\ Pokhara University \\ Email: esnbhattarai@gmail.com
}

\begin{abstract}
The aim of this study is to examine the social status of Nepalese single women and their perception on remarriage. For this purpose, out of 157 respondents, 128 single women (7.3\% margin of error and $90 \%$ Confidence level) of age 25 years to 80 years, from Pokhara Metropolitan City Ward No. 26 and 27 were interviewed purposively by using structured questionnaire. Descriptive statistics was used for the analysis of the data. Majority of single women were from age group of 40 years and above. Majority of them were illiterate and deprived from the political, social and economic participation. Major problems faced by the single women are economic hardship, family violence (especially mental tension given by the family and society), less freedom, deprivation of the social and economic rights and participations, less decision making roles and so on. Further, the majority of the single women had very little freedom to do something and go somewhere. It is also found that the land ownership has been transferred to them but it is due to legal provision after the death of husbands only. The result also shows that the single women faced the problem of loneliness. Majority of respondents think about remarriage without leaving children. It clearly shows that majority of the single women want to remarry not for physical pleasure but concerning about their safety, their children future and less economic burden. The study depicted that the barriers for the single women in social and religious participations have been changed slowly. It can be concluded that the social status of single women seems to be changing towards positive social status such as society has been liberal in their clothing and participation in various religious functions.
\end{abstract}

Keywords: Single women, widow, socio-economic, remarriage, violence

\section{Introduction}

Generally in Nepalese Context, the word 'Single woman' refers to the woman who has lost her husband and stays alone until she lives, also known as 'widow'. However, the feminist literatures define single woman as widow, divorced or separated. "Women who are unmarried over 35 years of age and women whose husband are dead "are called single women. In the 21st century, this word refers to all women who are widows, divorced, and separated and unmarried over 35 years of age.

Single women can be referred to those who are divorced with their spouses, who are abandoned by their husbands, whose husband are dead and those who are unmarried till the age 35 . Divorce single women are those who have legal ending of a marriage. Similarly, separate single women are those who stop living together as couples. Besides this, widow is defined as a woman

Journal of Development and Social Engineering

Volume 3 | Number 1 | December 2017, 49-58

ISSN 2382-5332 @ School of Development and Social Engineering, Pokhara University 
whose husband has died and who has not married again (Dhungana, 2014). The status of women is determined by the patriarchal social system, values, and women's right preserved and protected by the state, and state policy for the development of women.

Normally, the status of women in Nepalese society has been subordinate to men, right from the beginning. They have to undergo various kinds of discrimination, exploitation, and torture (i.e. the mental and physical problems) in society and they are regarded as the four walls of the family. As Nepalese society is highly dominated by patriarchy, women are oppressed greatly in a number of ways. Religious, rituals, social constructed norms and values have placed them out from the main works of the society. Nepalese society is still a traditional society that keeps women at a lower status than men, making them confined at home and the farmland they have. They are discouraged and prevented from taking part in public life. In the context of widow women naturally in such social phenomenon they have to face much adverse condition. It is considered that "the daughter is a thing to give away for someone else." These thoughts are evolved from the very beginning of the society. One of our major problems in our society is our inability to think critically about values that have been thrust upon us since ancient times (Subedi, 1997). Though the birth and death is universal truth, however the single women are largely blamed for the death of husband. The several situations occur as the social elites also perceive single women are accused. The social elites also perceived single women are accused. The societal leaders don't allow the widows in participating in societal and religious work (Malik, 2013).

The single women are more vulnerable and marginalized in the society because the lens of society is different and they treat them differently then and the cultural practice also puts constraints for single women. The man whose wife is dead and the man who is single, he can get remarried easily and adjusted in society but in case of women such practices is unthinkable or unacceptable. The cultural practice of Hindu myth also is of constraints for women because remarriage is perceived as $\sin$. Widows are not allowed to wear red clothes, bangles, tika, garland etc. They are not allowed to talk with unknown male. All these things are considered as 'sin', according to Hindu tradition. There is also the problem of social adjustment for a single woman in the society. Especially young widows are assumed to be witches and are blamed for the death of their husbands. On the other hand; widows are the ones who are blamed for their own condition. Although their husbands have been killed in the war or an accident, most of them think that their husband died because of their misfortune. They are most likely to become the victim of human trafficking because they have lack of education and skills to work and survive (Thapa, 2007).

Generally, in Nepal a woman's position is derived only from her relationship with the men under whose relational or legal protection she is. This is her father, brother, husband and then her son during her later years. In a Hindu society, religious and cultural practices have maintained implicit and explicit rules whereby the woman has restricted mobility, no decision-making and no access to resources. Poverty, illiteracy and the conflict situation force single women to seek refuge in informal sector and high chances of trafficking has occurred. The situation clearly shows that single women suffer both economically and emotionally. The rising number of young single women resulting from the armed conflict has forced them to tear away from the cultural and social codes and ethics and face the world with no skills and tools for earning driving them to trafficking and vulnerabilities.

In ancient Nepal, the society was characterized by the custom of 'Sati' which was highly praised in those times. It was assumed that when a widow burnt herself in the name of Sati, the sins of husband would be purified. This custom was believed to solve the economic and property inheritance problems of widows. During the Lichhavi dynasty the Sati custom was not made compulsory to the royal and high caste women. The women had to choose one of 
either to bear Sati or to follow 'Satibrat' "i.e. single women could not laugh in lauder voice, do merrymakings, enter temples, participate in social gatherings, and wear colourful clothes. They were not allowed to touch the materials made for gods and goddesses. It was believed that when she was present before someone's journey the journey would fail (Poudel, 2008). Moreover, the early marriage system still prevails in many parts of Nepal. Girls are married off before they have the opportunity to stand on their own feet. And if their husbands meet untimely deaths, there comes the question of survival. With the death of husband, a young widow who has to pass through a traumatic period losing her beloved - has to take care of her small children, old father-in-law and motherin-law. Likewise in ancient Nepal polygamy practice was prevailing and it was said that when the husband dies the widows would face problems to protect their virginity.

In Nepalese society, the inheritance rights of women depend on their marital or sexual status. Traditionally, a woman is only entitled to her husband's property if she is legally married and sexually faithful to him. A failure on either of these terms, whether real or alleged, results in the loss of her claims to her husband's estate. Legally, this should not be happening. Nepal has guaranteed equal rights for widows, but religious and societal norms have a more profound effect on the execution of these rights than the actual laws.

Women are considered to be a significant contributor in building a culture of peace and nurturing cultural practices. However, being a patriarchal society, it is no surprise to see single women living a dejected life ignoring every reason to be happy as if they have committed a sin. In Nepal, single women are also known as marginalized group (Berinstein, 2006), who are forced and sometimes prefer to live alone without men.

Although single women are the bread winner and active decision maker (Women Human Right Defenders [WHRD] 2005-2006), they are alienated from the community because they are denied to follow the social norms. Widows, Badi, divorced, and unmarried women are categorized under single women. Moreover, widows and Badi situations are more exacerbated than divorced and unmarried women. In Nepal, widows contain $99 \%$ of single women who are shunned by the society (Thapa, 2007). After the death of their husbands, their freedom is taken away by the society. According to census 2011, in Nepal 4.6\% of total female are single women as compared to $3.7 \%$ of total female single women in 2001 . This data trend reveals that the number of single women is increasing. Women for Human Rights reported that $67 \%$ of widows resulted from 10 years long armed conflict. Additionally, widows are merely between 2035 years of age with 3-4 children.

The armed conflict further added multidimensional issues on single women. Thousands of women have lost their husbands at a very young age due to the insurgency and many still live under profound emotional shock. Hundreds of them are displaced from various districts and working in the informal sector out of dire necessity, such as sex workers, in bars and as maids and helpers at a low rate of remuneration. Such single women are extremely vulnerable to abuse and torture. There is no concrete authentic data and information related to single women and no data on single women (widows) who have been displaced to urban areas and pushed into the informal employment sector. There is still no mechanism to address psychological trauma and mental distress of single women. There are no immediate trauma or relief centres that will assist single women and their children.

The issues of single women are not including in national policy level. They are also deprived from the justices and experiencing the problem of proper legal provision. According to Paudel (2008), "There are plenty of ridiculous laws that do not favour widows." There is also lack of access to education, caused low status of widows in society. They also faced economic dependency and it has affected the children especially in education. In terai child marriage is in practice and the child widow is one of the problems itself.

Social security allowance was introduced 
in 1994 A.D in Nepal by late Prime Minister Manmohan Adhikari of the United Marxist and Leninist (UML) party of Nepal. But this allowance is not sufficient for single women to survive their life. The government must pay attention on such problems of single women. On July 15, 2009, Nepal's government introduced a new incentive to give Rs. 50,000 cash as a reward for marrying a single woman (widow). The government has brought the program from the suggestion of economists for social security, but offering cash to marry widows only emphasize the fact that, women cannot be empowered until and unless they have husbands (Subedi, 1997).

Despite the 1990 revisions to the Constitution of Nepal, which guarantees women the "right to equality" in regard to inheritance to daughters was legally ensured only in 11th amendment of Civil Code (Muluki Ain) in 2002, such laws have not been enforced in which widows, ex-wives, divorcees, and rape victims are routinely denied their inheritances. Recognizing this, the Nepalese government has taken initiative to enforce its constitutional promises. One such initiative is the Civil Code (11th Amendment of the Muluki Ain), an Act passed in 2002, which grants widow's unfettered access and authority to the estate. The bill also removed the age restriction placed on widows, allowing them to claim property and even live independently of their husbands' families after their deaths. However, a weakness of the bill is that the widow must return the remaining inheritance to the late husband's heirs if she remarries.

After the strong suggestions to the government by CEDAW committee in 2004, there have been some changes in the discriminatory laws, mostly through the Eleventh Amendment to the country code of Nepal resulted single women's rights to property. The government has taken some initiatives to implement or monitor their actual implementation but only for conflict made single women bypassed other marginalized single women. The government also started some social security measures to address the needs of single women by providing compensation to the spouse of deceased, scholarships, services at health posts and identifying the measures through program planning. In the context of Nepal, issues of single women have been under the shadow of other contemporary issues. There are very few studies on the social status of single women and their perception on remarriage.

Therefore, this study aims to examine the socio-economic status and their perception on remarriage in the context of Nepalese single women.

\section{Data and Methods}

At first stage, out of 33 wards in Pokhara Metropolitan City, two wards (ward number 26 and 27) were selected purposively. According to Pokhara Metropolitan City profile (2074), there were 84 single women in Ward No. 26 and 73 in Ward No. 27, with grand total of 157 single women. So, the total population for this study was 157 . At second stage, out of 157 respondents, the primary data was collected purposively from 128 single women of age group of 25 to 80 years. Structured questionnaire was used to gather information from 157 respondents using interview techniques. Descriptive statistics was used to analyze the data.

\section{Result and Discussion}

Socio-demographic and Socio- economic characteristics of the respondents

This study has delineated age, family type and size, caste/ethnicity, religion, educational attainment, monthly-income and land ownership as the concerning social, demographic and economic factors.

Age of the respondent: Age is one of the main and concerned matters of demographic factors for analysis of this study. Age in this study refers to the age of the respondent who is a single woman. The Minimum age of the respondents surveyed in this study was 28 years and the maximum age was 84 years with the mean age of 58.09 years. Of the total respondents of this study, nearly half of the respondents (46.9\%) were in age group 40 years and above, 28.1 percent in age group 
25-30 years, 14.1 percent in age group 30-35 years, and only 10.9 percent in age group 35 40 years respectively (table 1 ).

Family type and size: Traditionally, the Nepalese societies were popular for joint family where different generations used to live jointly together. This study also revealed the same trend of family structure. Among the total respondents of this study, more than half $(56.3 \%)$ were living in the joint family against less than half (43.7\%) nuclear family (table 1).

The largest family surveyed for the purpose of this study had 12 members (a joint family) and the smallest family had single member (a nuclear family). The average size of the family was about 6 members (mean statistics 5.49). Furthermore, more than one-third of the households surveyed (35.9\%) had 5-7 members in their families followed by more than seven members $(33.1 \%)$ and less than or equal to four members (31\%) respectively (table 1). The average family size found in this study was slightly higher than the census statistics (average family size 4.76; CBS, 2011).

Caste/ ethnicity: Caste/ethnicity of an individual also indicate his/her role in the in the family. Generally, it is found that Janajati women in Nepal have more social as well as economic freedom and also control on household related decision-makings compared to women in other caste/ethnic groups. In this study, only three different major castes and ethnic groups namely Brahmin, Chhetri and Janajati were recorded along with very few others. Of the total respondents surveyed, more than one-third of the respondents (35.2\%) were Chhetri followed by Brhamin with nearly equal proportion (34.4\%), Janajati $(19.5 \%)$ and others $(10.9 \%)$ respectively (table 1$)$. The population in the study area has nearly equal concentration of both Chhetri and Brhamin.

Religion: Religion strongly determines the attitudes and behavioural pattern and style of individuals. Religion is known as the base of norms, values and cultural pattern of any society and family. Different religious have their own norms, values and cultural pattern. Generally, women in the Buddhist families in Nepal are assumed to enjoy greater freedom than the women in other religions. The study divides the religion of the respondents into three groups as Hindu, Buddhist and Christian. A large majority of the respondents (85.94\%) surveyed were Hindu followed by Buddhist (12.50\%) and Christian (1.5\%) (table 1).

Educational attainment: It is one of the basic needs of human and helps to broaden human knowledge, thus making them more wise and rational. For the purpose of this study, educational attainment of the respondents was classified into illiterate, literate, primary level, secondary level, higher secondary level and bachelor and above. Of the total respondents, more than half of the respondents (53.1\%) were illiterate, followed by literate $(18.8 \%)$, primary level $(6.3 \%)$, secondary level $(12.5 \%)$, higher secondary level (7.8\%), and only very few respondents (1.6\%) had completed Bachelor and above (table 1).

Monthly income: Income is one of the important economic aspects of an individual, which is essential for maintaining the standard of living. This study found that nearly half of the respondents (48.4\%) had the average monthly income. This figure also includes the single women allowance (i.e. Social security allowance).

Land ownership: Land ownership is also an important economic aspect of an individual. In the context of Nepal, holding of ownership of land determines the social as well as economic status of an individual. Generally speaking, single women had own land property due to the legal provision after the death of husband. This study depicted that large majority of the respondents (81.2\%) had their own land and they fully control their resources against only few $(18.8 \%)$ had not their own land (table1). 
Table 1: Distribution of respondents by socio-demographic and socio-economic characteristics $(\mathrm{N}=128)$

\begin{tabular}{|c|c|c|c|}
\hline Variable & Category & Number & Percent \\
\hline \multirow{4}{*}{ Age group (years) } & $25-30$ & 36 & 28.1 \\
\hline & $30-35$ & 18 & 14.1 \\
\hline & $35-40$ & 14 & 10.9 \\
\hline & 40 and above & 60 & 46.9 \\
\hline \multirow{2}{*}{ Family type } & Joint family & 72 & 56.3 \\
\hline & Nuclear family & 56 & 43.7 \\
\hline \multirow{3}{*}{ Family size } & Less than or equal to 4 member & 40 & 31.25 \\
\hline & 5-7 member & 46 & 35.93 \\
\hline & More than 7 member & 42 & 32.81 \\
\hline \multirow{4}{*}{ Caste/ ethnicity } & Brahmin & 44 & 34.4 \\
\hline & Chhetri & 45 & 35.2 \\
\hline & Janajati & 25 & 19.5 \\
\hline & Others & 14 & 10.9 \\
\hline \multirow{3}{*}{ Religion } & Hindu & 110 & 85.94 \\
\hline & Buddhist & 16 & 12.50 \\
\hline & Christian & 2 & 1.5 \\
\hline \multirow{6}{*}{ Education } & Illiterate & 68 & 53.1 \\
\hline & Literate & 24 & 18.8 \\
\hline & Primary & 8 & 6.3 \\
\hline & Secondary & 16 & 12.5 \\
\hline & Higher secondary & 10 & 7.8 \\
\hline & Bachelor and above & 2 & 1.6 \\
\hline \multirow{4}{*}{ Monthly income } & Less than NRs 5000 & 24 & 18.8 \\
\hline & More than NRs 5000 & 36 & 28.1 \\
\hline & Less than NRs 10000 & 6 & 4.7 \\
\hline & More than NRs 10000 & 62 & 48.4 \\
\hline \multirow{2}{*}{ Land ownership } & Yes & 104 & 81.2 \\
\hline & No & 24 & 18.8 \\
\hline
\end{tabular}

Source: Field Survey 2017

\section{Social Status of respondents}

Causes of Being Single Women (Widowhood): The causes of being single women (widowhood) are categorized as old age of husband, Maoist insurgency period and accident and health issues. This study revealed that more than three-fourth of the respondents $(78.90 \%)$ became single due to the death of their old aged husband, followed by Maoist insurgency $(10.93 \%)$ with equal proportion of Accident and health issues $(10.17 \%)$ respectively (table 2 ).

Table 2: Causes of being single women (widowhood) $(\mathrm{N}=128)$

\begin{tabular}{lcc}
\hline \multicolumn{1}{c}{ Causes } & Number & Percent \\
\hline Old age of husband & 101 & 78.90 \\
Maoist Insurgency & 14 & 10.93 \\
Accident and health issue & 13 & 10.17 \\
\hline
\end{tabular}

Source: Field Survey 2017 
Problem faced by single women: This study has identified family violence and its types and social deprivation as the major problem faced by single women. Though the level of violence has been decreased due to the improvement in educational status and selfdependencies but still single women are not free from family violence completely, they are facing some sort of family violence.

Caste and family violence: The level of violence depends upon caste/ethnicity of an individual. Generally, in Nepalese societies,
Dalit women are suffering higher level of violence in their family as well as society. Though this study reflected that women oppression and discrimination is gradually decreased due to the level of education and economic self- reliance but single women from both Brhamin and Chhetri (nearly equal proportion of $34.4 \%$ and $35.2 \%$ respectively) were suffered from some sort of violence followed by Janajati single women (19.9\%) with few other single women (10.9\%) suffered from the same (table 3).

Table 3: Caste and family violence $(\mathrm{N}=128)$

\begin{tabular}{lcccccc}
\hline & \multicolumn{3}{c}{ Family violence } & \multicolumn{2}{c}{ Total } \\
\cline { 2 - 6 } Caste & \multicolumn{2}{c}{ Yes } & \multicolumn{2}{c}{ No } & \multicolumn{2}{c}{} \\
\cline { 2 - 6 } & Number & Percent & Number & Percent & Number & Percent \\
\cline { 2 - 6 } & 18 & 18 & 26 & 59 & 44 & 34.4 \\
Bhramin & 18 & 40 & 27 & 60 & 45 & 35.2 \\
Chettri & 9 & 36 & 16 & 64 & 25 & 19.5 \\
Janajati & 7 & 50 & 7 & 50 & 14 & 10.9 \\
Other & 2017 & & & & & \\
\end{tabular}

Source: Field Survey 2017

Types of family violence faced by respondents: Single women faced various sorts of family violence, among which large majority $(80.76 \%)$ of the respondents who faced family violence were suffering from mental violence followed by physical violence $(15.38 \%)$ with even suffering from sexual violence $(3.84 \%)$ respectively (table 4$)$.

Table 4: Types of family violence $(\mathrm{N}=52)$

\begin{tabular}{lcc}
\hline Category & Number & Percent \\
\hline Physical & 8 & 15.38 \\
Mental & 42 & 80.76 \\
Sexual & 2 & 3.84 \\
\hline
\end{tabular}

Source: Field Survey 2017

Social deprivation and its causes: Single women are deprived from enjoying various sorts of facilities within family as well as in society. Mostly, single women were deprived of social, economic and political participation due to the lack of education. This study reflected that majority of respondents $(73.4 \%)$ were deprived due to lack of education, followed by tradition and culture
(12.5\%), gender discrimination $(6.2 \%)$, low economic status $(4.7 \%)$ with few lack of awareness $(3.1 \%)$ respectively.

The study reflected that, majority of Chhetri single women (29.7\%) were socially deprived due to lack of education and the followed same trend in remaining caste as well (table 5). 
Table 5: Causes of social deprivation of respondents $(\mathrm{N}=128)$

\begin{tabular}{|c|c|c|c|c|c|c|c|c|c|c|c|c|}
\hline \multirow{3}{*}{ Caste } & \multicolumn{10}{|c|}{ Cause of women's being deprived in society } & \multirow{2}{*}{\multicolumn{2}{|c|}{ Total }} \\
\hline & \multicolumn{2}{|c|}{$\begin{array}{l}\text { lacks of } \\
\text { education }\end{array}$} & \multicolumn{2}{|c|}{$\begin{array}{c}\text { Lack of } \\
\text { awareness }\end{array}$} & \multicolumn{2}{|c|}{$\begin{array}{c}\text { Gender } \\
\text { discrimination }\end{array}$} & \multicolumn{2}{|c|}{$\begin{array}{c}\text { Low } \\
\text { economic } \\
\text { Status }\end{array}$} & \multicolumn{2}{|c|}{$\begin{array}{l}\text { Traditional } \\
\text { and culture }\end{array}$} & & \\
\hline & No. & $\%$ & No. & $\%$ & No. & $\%$ & No. & $\%$ & No. & $\%$ & No. & $\%$ \\
\hline Bharmin & 31 & 24.2 & 2 & 1.6 & 2 & 1.6 & 3 & 2.3 & 6 & 4.7 & 44 & 34.4 \\
\hline Chetttri & 38 & 29.7 & 1 & 0.8 & 2 & 1.6 & 1 & 0.8 & 3 & 2.3 & 45 & 35.2 \\
\hline Janajati & 15 & 11.7 & 1 & 0.8 & 3 & 2.3 & 1 & 0.8 & 5 & 3.9 & 25 & 19.5 \\
\hline Other & 10 & 7.8 & 0 & 0.0 & 1 & 0.8 & 1 & 0.8 & 2 & 1.6 & 14 & 10.9 \\
\hline Total & 94 & 73.4 & 4 & 3.1 & 8 & 6.2 & 6 & 4.7 & 16 & 12.5 & 128 & 100.0 \\
\hline
\end{tabular}

Source: Field Survey 2017

Single women in eyes of educated and uneducated people: Educated people are wiser towards single women as compared to uneducated ones. This study showed that majority of respondents expressed that being single is simple in the eye of educated as well as uneducated people $(73.4 \%$ and $42.2 \%$ respectively ), but nearly equal proportion of respondents (37.5\%) said that being single is bad in the eye of uneducated people (table 6).

Table 6: Single women in eyes of educated and uneducated people $(\mathrm{N}=128)$

\begin{tabular}{lcccccccccc}
\hline $\begin{array}{l}\text { Single women } \\
\text { in the eyes of } \\
\text { uneducated } \\
\text { person }\end{array}$ & \multicolumn{9}{c}{ Single women in the eyes of educated person } & \multicolumn{2}{c}{ Total } \\
\cline { 2 - 9 } & \multicolumn{2}{c}{ Good } & \multicolumn{2}{c}{ Simple } & \multicolumn{2}{c}{ Bad } & Do not know & & \\
\cline { 2 - 10 } & No. & Percent & No. & Percent & No. & Percent & No. & Percent & No. & Percent \\
\hline Simple & 6 & 4.7 & 44 & 34.4 & 4 & 3.1 & 0 & 0 & 54 & 42.2 \\
Bad & 6 & 4.7 & 40 & 31.2 & 2 & 1.6 & 0 & 0 & 48 & 37.5 \\
Don't know & 8 & 6.2 & 10 & 7.8 & 2 & 1.6 & 6 & 4.7 & 26 & 20.3 \\
\hline Total & $\mathbf{2 0}$ & $\mathbf{1 5 . 6}$ & $\mathbf{9 4}$ & $\mathbf{7 3 . 4}$ & $\mathbf{8}$ & $\mathbf{6 . 2}$ & $\mathbf{6}$ & $\mathbf{4 . 7}$ & $\mathbf{1 2 8}$ & $\mathbf{1 0 0 . 0}$ \\
\hline
\end{tabular}

Source: Field Survey 2017

Perception of respondent (single women) towards remarriage: Generally speaking, remarriage is not allowed in Nepalese societies due to existence of various sociocultural and religious beliefs. Remarriage after the death of husband is generally taken as sin. Nowadays, as the awareness level of people is increasing due to educational attainment, perceptions of people towards remarriage got changed so the rate of remarriage is in increasing trend. It is also supported by government policy of giving incentives for the couple after marrying with single women (widow).
Age and perception of respondents towards remarriage: Age is major socio-demographic factor determining the perception of people towards remarriage. Generally speaking, the perception of people towards remarriage becomes positive at their higher age as they feel loneliness and need life support. This study also revealed that large majority of respondents $(90.6 \%)$ had positive perception towards remarriage against only few $(9.4 \%)$ with negative perception. Majority of single women $(42.2 \%)$ of age group 60 years and above had positive perception towards remarriage due to past experience of their life (table 7). 
Table 7: Age and perception of respondents towards remarriage $(\mathrm{N}=128)$

\begin{tabular}{lcccccc}
\hline \multirow{2}{*}{ Age } & \multicolumn{3}{c}{ Perception towards the remarried widow } & \multicolumn{2}{c}{ Total } \\
\cline { 2 - 5 } & \multicolumn{2}{c}{ Positive } & \multicolumn{2}{c}{ Negatives } & \multicolumn{2}{c}{ Percent } \\
\cline { 2 - 5 } & No. & Percent & No. & Percent & No. & Pernyyynn \\
\hline $20-30$ & 6 & 4.7 & 0 & 0 & 6 & 4.7 \\
$30-40$ & 14 & 10.9 & 0 & 0 & 14 & 10.9 \\
$40-50$ & 24 & 18.8 & 4 & 3.1 & 28 & 21. \\
$50-60$ & 18 & 14.1 & 2 & 1.6 & 20 & 15.6 \\
60 above & 54 & 42.2 & 6 & 4.7 & 60 & 46.9 \\
\hline Total & $\mathbf{1 1 6}$ & $\mathbf{9 0 . 6}$ & $\mathbf{1 2}$ & $\mathbf{9 . 4}$ & $\mathbf{1 2 8}$ & $\mathbf{1 0 0 . 0}$ \\
\hline
\end{tabular}

Source: Field Survey 2017

Age and interest of respondents in remarriage: Though perceptions of people towards getting remarriage seem to be positive at higher age group but they are not interested for remarrying due to their prime responsibility of rearing and caring of their children and other social barrier. In this study, it was found that large majority of respondents $(90.6 \%)$ were not interested in remarriage against only few $(9.4 \%)$ with an interest of remarriage. Out of total 128 respondents surveyed for the study, only 12 respondents were interested in remarriage, in which 8 respondents were from the age group 25-30 years against nil in age group 40 years and above (table 8).

Table 8: Age and interest of respondents in remarriage $(\mathrm{N}=128)$

\begin{tabular}{lcccccc}
\hline \multirow{2}{*}{$\begin{array}{c}\text { Age at } \\
\text { widowhood }\end{array}$} & \multicolumn{3}{c}{ Interested in Remarriage } & \multicolumn{2}{c}{ Total } \\
\cline { 2 - 6 } & \multicolumn{2}{c}{ Yes } & \multicolumn{2}{c}{ No } & \multicolumn{2}{c}{} \\
\cline { 2 - 6 } & Number & Percent & Number & Percent & Number & Percent \\
\hline $25-30$ & 8 & 6.25 & 28 & 21.87 & 36 & 28.12 \\
$30-35$ & 2 & 1.57 & 16 & 12.5 & 18 & 14.1 \\
$35-40$ & 2 & 1.57 & 12 & 9.4 & 14 & 10.9 \\
40 above & 0 & 0.0 & 60 & 46.9 & 60 & 46.9 \\
\hline Total & $\mathbf{1 2}$ & $\mathbf{9 . 3 3}$ & $\mathbf{1 1 6}$ & $\mathbf{9 0 . 6 7}$ & $\mathbf{1 2 8}$ & $\mathbf{1 0 0}$ \\
\hline
\end{tabular}

Source: Field Survey 2017

Religion and remarriage: Religion is also an important factor for determining the perception and interest of people towards remarriage. Hindu religion is more rigid towards remarriage as compared to other religion as it considered doing remarriage after the death of husband is sin. Out of 128 respondents surveyed, 106 following Hindu religion, only 25.0 percent want remarriage without leaving their children.
Similarly, 16 out of 128 respondents following Buddhism, 8 percent want remarriage without leaving their children whereas no respondent following Christian were interested in remarriage (table 9).This study showed clear majority of respondents doesn't want to remarriage because of social barrier, their age factors and responsibility towards their children.

Table 9: Religion and remarriage $(\mathrm{N}=128)$

\begin{tabular}{ccccccccc}
\hline Remarriage & \multicolumn{9}{c}{ Religion } & \multicolumn{2}{c}{ Total } \\
\cline { 2 - 8 } $\begin{array}{c}\text { without } \\
\text { leaving } \\
\text { children }\end{array}$ & \multicolumn{2}{c}{ Hindu } & \multicolumn{2}{c}{ Christian } & \multicolumn{2}{c}{ Buddhism } & & \\
\cline { 2 - 8 } & Number & Percent & Number & Percent & Number & Percent & Number & Percent \\
\hline Yes & 32 & 25 & 0 & 0 & 8 & 6.25 & 40 & 31.25 \\
No & 78 & 60.93 & 2 & 1.5 & 8 & 6.25 & 88 & 68.75 \\
\hline Total & $\mathbf{1 1 0}$ & $\mathbf{8 5 . 9 3}$ & $\mathbf{2}$ & $\mathbf{1 . 5}$ & $\mathbf{1 6}$ & $\mathbf{1 2 . 9}$ & $\mathbf{1 2 4}$ & $\mathbf{1 0 0}$ \\
\hline
\end{tabular}

Source: Field Survey 2017 
Education and remarriage: Education is another important factor for determining remarriage. Generally speaking, higher the qualification, more wiser towards remarriage. This study revealed that more than half of the respondents (51.3\%), who are illiterate were not interested for remarriage with only 6.2 percent of respondents with higher secondary level education were interested in remarriage (table10).

Table 10: Education and remarriage $(\mathrm{N}=128)$

\begin{tabular}{|c|c|c|c|c|c|c|}
\hline \multirow{3}{*}{$\begin{array}{l}\text { Education and } \\
\text { qualification }\end{array}$} & \multicolumn{4}{|c|}{ Interested in Re-marriage } & \multirow{2}{*}{\multicolumn{2}{|c|}{ Total }} \\
\hline & \multicolumn{2}{|c|}{ Yes } & \multicolumn{2}{|c|}{ No } & & \\
\hline & No. & Percent & No. & Percent & No. & Percent \\
\hline Illiterate & 0 & 0.0 & 68 & 53.1 & 68 & 53.1 \\
\hline Literate & 0 & 0.0 & 24 & 18.8 & 24 & 18.8 \\
\hline Primary level & 2 & 1.6 & 6 & 4.7 & 8 & 6.2 \\
\hline Secondary level & 2 & 1.6 & 14 & 10.9 & 16 & 12.5 \\
\hline Higher secondary level & 8 & 6.2 & 2 & 1.6 & 10 & 7.8 \\
\hline Bachelors or above & 0 & 0.0 & 2 & 1.6 & 2 & 1.6 \\
\hline Total & 12 & 9.4 & 116 & 90.6 & 128 & 100.0 \\
\hline
\end{tabular}

Source: Field Survey 2017

\section{Conclusion}

The socio-economic status of single women in Nepal is very poor. The women are being discriminated in every aspect of the society. A woman who is a widow is discriminated against, abused, harassed and deprived of social and economic rights, including property rights. There are many cases of young widows being vulnerable and victimized - both sexually and emotionally within the family and in their communities. Religious beliefs, cultural values and social norms further prohibit the young women from taking part in any family or public activities. It is necessary to develop the widow policies regarding their inherent right, ownership and remarriage right. The government supports for the empowerment of single women by promoting the rights, participation, equality and freedom. Single women problem and their challenges and the condition of remarriage of widow, the government and society need to help them.

\section{Acknowledgements}

This study is based on the data collected for the Master's Degree dissertation of the second author. The dissertation has been submitted to the School of Development and
Social Engineering, Faculty of Humanities and Social Sciences, Pokhara University in 2018.

\section{References}

Berinstein, K. (2006). Introduction: The Situation on Widows. SAAPE Newsletter, 3(1).

Dhungana, R. K. (2014). Nepali Hindu women's thorny path to liberation. Journal of Education and Research, 4(1), 39-57.

CBS. (2011). Population census. Kathmandu: Government of Nepal.

Malik, V. (2013). Problems of Widow Remarriage In India: A Study. Journal of Business Management \& Social Sciences Research, 2(2), pp.23-31.

Paudel, M.(2008). Socio- Economic and Demographic Status of Single Women, An Unpublished Thesis Submitted to Central Department of Population Studies, Tribhuvan University, and Kathmandu.

Subedi, P. (1997). Nepali Women Rising .Sayogi Press, Kathmandu.

Thapa, L. (2007). "Nepal Widows" retrieved from - www.opendemocracy.net "Progress for Women Is Progress for All." UNIFEM Fact Sheet 2008: 